\title{
Effects of abiotic parameters main of soil on the distribution of earthworms in a tropical moist savanna (Lamto, Central Côte d'Ivoire)
}

\author{
Nounfro Madjima SORO*, N'guetta Moïse EHOUMAN, Mamadou TOURE et \\ Seydou TIHO \\ UFR des Sciences de la Nature (SN), Université Nangui Abrogoua, 02 BP 801 Abidjan 02, Côte d'Tvoire. \\ Unité de Recherche en Ecologie et Biodiversité (UREB), Université Nangui Abrogoua, Côte d'Tvoire. \\ *Corresponding author; E-mail: soromadjima@yahoo.fr, Tel: +22505849892 /+22507039949
}

\begin{abstract}
The distribution of earthworms fluctuates in relation to vegetation type and environmental factors. This study evaluates the effects of litter input, organic matter, soil moisture and $\mathrm{pH}$ on the structure and relative abundance of earthworms collected from different vegetation of Lamto reserve. Grassy savanna, woody savanna and Forest were sampling. Each vegetation type has been divided into 3 plots. These plots were georeferenced using a GPS and mapped using QGIS software. For each plot, 25 points were randomly selected using their GPS coordinates. The litters were collected manually. In TSBF (Tropical Soil Biology and Fertility) monoliths of the earthworms have been collected by handsorting. Soil clumps were also collected to determine the organic matter contain, soil moisture and $\mathrm{pH}$. The woody savanna contained the greatest number of earthworm species followed by the grassy savanna and the forest that had the same number of species. Whereas, forest has the highest density of earthworms, followed by grassy and woody savannas. The moisture of soil influences the distribution of earthworm in forest. In grassy savanna the distribution of earthworm depends on soil moisture and organic matter. In woody savanna, the distribution of earthworm depends on soil moisture, $\mathrm{pH}$ and biomass of litter.
\end{abstract}

(c) 2019 International Formulae Group. All rights reserved

Keywords: Earthworms, distribution, soil abiotic parameters, vegetation type, Lamto.

\section{INTRODUCTION}

Earthworm belongs to one of the most important invertebrate groups of the class Oligochaeta under the phylum Annelida and is well known for its contribution to soil formation. They occupy a place important in ecosystems. Earthworms plays an important role in the incorporation, transformation of materials and improve soil structure (Decaens and Jiminez, 2002). Through their activities, earthworms are real actors and bioindicators of the soil fertility (Milau et al., 2015). Since earthworms have been recognized for their critical role in ecosystem stability, several studies have focused on the factors that govern the dynamics and distribution of earthworms in the soil. The species of earthworms found in an environment depend on nature, soil characteristics and conditions climate change (Gastine et al., 2003). Their structure and distribution mode in the soil are various. The significance of diverse soil habitats is one of the most influencing factors affecting the overall earthworm distribution (Rajkhowa et al., 2014). Population dynamics, diversity and distribution of earthworms in natural ecosystems of the tropics have received considerable attention in recent years 
(Gonzalez et al., 2007). Several works studied the habitat preference of various earthworm species (Scullion and Malik, 2000). The presence of a species in a particular habitat and its absence from other habitats shows the species-specific distribution of earthworms in ecosystems (Tripathi and Bhardwaj, 2004). The distribution of earthworm communities also depends on the physico-chemical characteristics of the soil. Environmental factors such as moisture, temperature, $\mathrm{pH}$ and soil texture also affect the distribution of earthworms (Fokam et al., 2016). Changes in land use patterns have also directly affected the composition and population structure of earthworm communities in different agroclimatic regions (Lalthanzara et al., 2011; Traoré et al., 2012; Savadogo et al., 2016; Empwal et al., 2017). Others studies evalued the effects of abiotic factors on the structure of earthworm community (Singh et al., 2016). Koné et al. (2012) highlighted the influence of environmental factors, including litter and soil parameters, on the abundance of earthworms. Ehouman et al. (2012) showed that the structure of the earthworm community varied according to the type of vegetation. However, no study has shown the abiotic factors determining the distribution of earthworms in each type of vegetation. This study aims to determine which abiotic parameter influences the distribution of earthworms in each vegetation type of the natural reserve of Lamto.

\section{MATERIALS AND METHODS Site description}

The study was conducted in Lamto reserve $\left(6^{\circ} 13 \mathrm{~N}, 5^{\circ} 2 \mathrm{~W}\right)$ in Central Côte d'Ivoire from May to September 2015. The reserve belongs to the transition zone between the semi-decidous humid forest in the South and Soudanian savannas in the North. Lamto reserve has an area of 2700 ha covered by mosaic of forest and savanna. Lamto is characterized by a bimodal rainfall indicating two wet seasons from April to July and from September to October. From 2006 to 2015 the average rainfall is $1240 \mathrm{~mm}$, the maximum being reached in June with $177.44 \mathrm{~mm}$ of rain. determined using the taxonomic guide developed by Cszudi and Tondoh (2007).
The lowest rainfall occurs in December with $22.12 \mathrm{~mm}$. The average minimum temperature is in August: $26.44{ }^{\circ} \mathrm{C}$, and the maximum in February: $29.99^{\circ} \mathrm{C}$. Most soils lie on granitic bedrock and are classified as ferralsols. The habitats studied were chosen according to vegetation type. The grassy savanna consists mainly of grasses, the woody savanna with grasses and trees both, the forest of trees mainly.

\section{Sampling design}

Three vegetation types (Grassy and woody savannas, and Forest) were sampling. Each vegetation was represented by 3 plots. Each plot was first geo-referenced using a Global Positioning System (GPS) (GARMIN Montana 600). The geo-reference data were used to generate the maps of the different plots using the QGIS2.6.0 software (Figure1). Within each plot, 25 squares $(5 \times 5 \mathrm{~m})$ were randomly selected from their geographic coordinates to collect litter, earthworms and soil clods. A total of 75 monoliths were sampled in each vegetation type.

\section{Litter biomass, earthworms, and soils abiotic parameters sampling}

In the different vegetation type (forest, woody and grassy savannas), litter was collected in 25 squares of $5 \mathrm{~m}$ size. Litter of each square is placed in newspaper with mentions (Type, date, site name and square number). To determine the litter biomass, litters collected were dried in an oven at 105 ${ }^{\circ} \mathrm{C}$ for 48 hours. The masses of dry matter obtained were measured using a precision Sartorius-type balance 0,1 .

After litter collect, modified TSBF monoliths $(50 \mathrm{~cm} \times 50 \mathrm{~cm} \times 30 \mathrm{~cm})$ were dug at the intersection of the main diagonals. Earthworms were sampled by the hand-sorting method up to $30 \mathrm{~cm}$ deep using quadrats $(50 \mathrm{x}$ $50 \mathrm{~cm}^{2}$ area) for each sampling site (Lavelle, 1978). All earthworms were preserved in $4 \%$ formaldehyde. Individuals were then separated in the laboratory into species, counted and weighed. Species were 
The main soil abiotic parameters (organic matter, $\mathrm{pH}$, and soil moisture) were also determined to assess their impact on the distribution of earthworms in the soil. The $\mathrm{pH}$ was determined using a Mettler-ToledoGmBH MP pH meter. At each monolith, soil sample were taken at $0-20 \mathrm{~cm}$ depth. To determine soil moisture, a part of soil cores was immediately weighed for fresh mass. The sample was then placed in a steam room at $105{ }^{\circ} \mathrm{C}$ for 48 hours, and weighed for dry mass. The other part of soil was air-dried, crushed and sieved $(2 \mathrm{~mm})$ before the determination of the organic matter and $\mathrm{pH}$. $\mathrm{pH}$ values were measured electronically on soil-to water suspensions (Baize, 2000). $5 \mathrm{~g}$ of dry soil was combustined using a LECO CNS 2000 analyzer (LECO Corporation, St Joseph, MI) at a temperature of $375^{\circ} \mathrm{C}$ for 16 hours (Moreno et al., 2001). The organic matter content is obtained by multiplying the ratio of the difference between the weight of the dry soil and the weight of the incinerated soil on the weight of the dry soil per 100.

Soil moisture was obtained by

$\frac{\text { Fresh weight-Dry weight }}{\text { Fresh weight }} \times 100$ and organic matter content by

$\frac{\text { weight not burned-burned weight }}{\text { weight }} \times 100$

\section{Statistical analysis}

The species richness of earthworms was determined by enumerating the number of species observed over the whole monoliths. The density of earthworms was defined as the number of individual per $\mathrm{m}^{2}$ area. Shannon-Weaver's index served to measure the diversity of the earthworm community. This index and its evenness were computed using the program EstimateS 7.50. The Statistica version 7.1 software allowed verifying the homogeneity of the variances by the Levene test. Then, the overall variability of earthworm densities of the different sites was determined with the nonparametric Kruskal-Wallis test. Finally, the Mann-Withney U test was used to compare 2 to 2. To investigate the effects of environmental variables (Litter biomass, soil $\mathrm{pH}$, soil organic matter and soil moisture content on species abundances, we use an ordination method (gradient method analysis) developed by (Lebreton et al. 1988) in order to summarize all the information in the community. Thus canonical correspondence analysis (CCA) was used. The aim of canonical ordination is to detect the main pattern in the relation between the species and the observed environment (Jongman et al. 1995). The function ade 4 of programme $R$ was used to establish the structure of the community of earthworms.

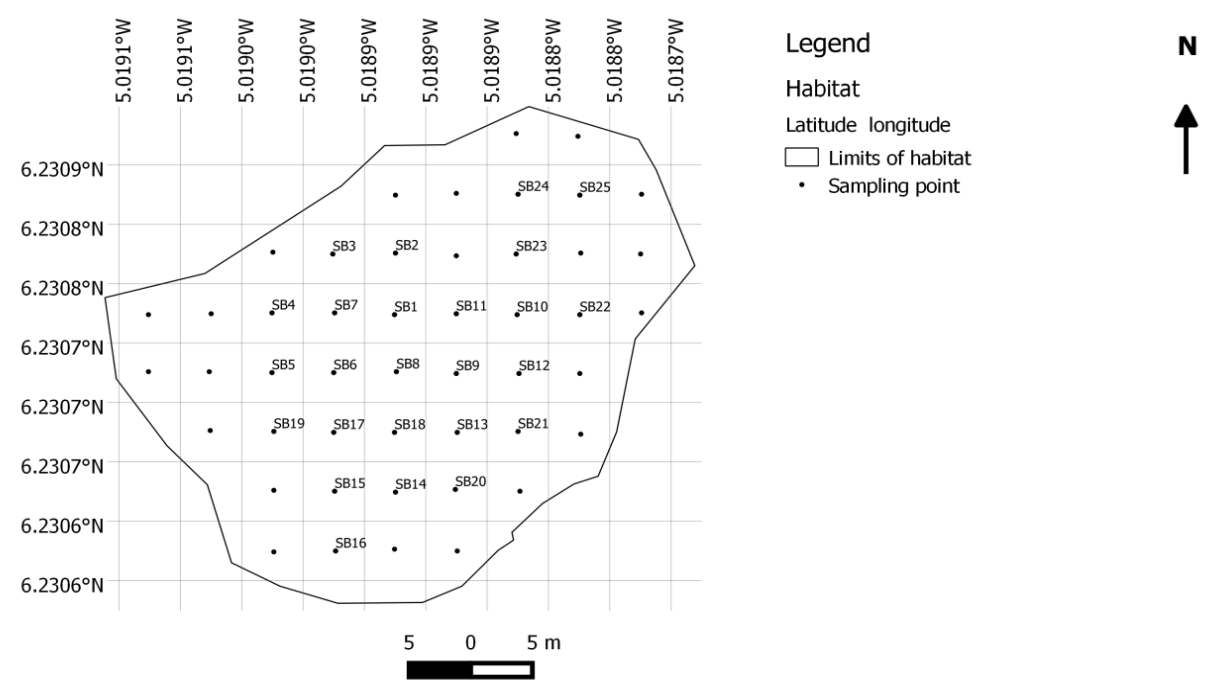

Figure 1 : Sampling design. 


\section{RESULTS}

\section{Sampling efficiency}

The species richness observed was a very good estimate of that expected in each habitat. The values of sampling coverage were high for all habitats (at least 84\%). The woody savanna contained the largest number of species (13 species) followed by grassy savanna and forest (12 species each). The grassy savanna had the lowest value of the diversity index $(H=1.89)$. This value is 2.12 for wooded savanna and 2.19 for forest. The value of Equitability is the same in all vegetation type $(E=0.98$, Table 1$)$.

\section{Density of earthworms}

The density of earthworms was high in forest following by grassy savanna. Woody savanna had low density. In grassy savanna the highest densities were recorded for the species Sthulmania porifera, Chuniodrilus palustris and Millsonia omodeoi. In woody savanna Sthulmania porifera, Millsonia omodeoi and Dichogaster agilisweree dominated species. However, in the forest, Sthulmania porifera, Chuniodrilus palustris and Dichogaster agilis had the highest densities (Table 2). The comparison of mean densities of earthworms in different media reveals the existence of significant differences between them (Kruskal-Wallis test: $\mathrm{F}=15.05$, $\mathrm{P}<0.05)$. The Mann-Whitney U test showed a significant difference between the density of earthworms in grassy and woody savannas; between the grassy savanna and that of the forest, and between the woody savanna and that of the forest ( $\mathrm{P}<0.05$ for each).

\section{Effect of environmental variables on species distribution by habitat type}

Three soil environment variables (litter biomass, proportion of organic matter, soil moisture content and soil $\mathrm{pH}$ ) were measured. The litter biomass, organic matter and soil moisture content were high in forest following by woody savanna. Grassy savanna had low litter biomass, organic matter and soil moisture content (Table 3).

\section{Effect of environmental variables on species distribution}

Four environmental variables (Biomass of litter, organic matter, soil moisture and soil $\mathrm{pH})$ were measured.

\section{Grassy savanna}

The proportion explained by the relationship between earthworms and environmental variables was $43.59 \%$ (Table 4a). The canonical coefficients of the environmental variables are presented in Table $4 \mathrm{~b}$ and the scores of each earthworm species in Table 4c. The first four axes of the canonical correspondence analysis (CCA) explain $67.66 \%$ of the variability of the species. The axis 1 formed by the gradient of soil moisture and organic matter explains to 27.38 the variance of earthworms. The axis 2 formed by the gradient of $\mathrm{pH}$ and litter explains to $16.21 \%$ the variance of earthworms. The earthworm species that form the axis1 are Agastrodrillus multivesiculatus, Chuniodrilus palustris, Dichogaster agilis, Millsonia omodeoi, Stuhlmannia proriferaand the earthworm species that form the axis 2 are Dichogaster baeri, Dichogaster saliens, Dichogaster terrae-nigrae, Millsonia lamtoiana (Figure 2).

\section{Woody savanna}

The variance explained by the relationship between earthworms and environmental parameters was $47.52 \%$ (Table 5a). The canonical coefficients of the environmental variables are presented in Table $5 b$ and the scores of each earthworm species in Table 5c.The first four axes of the canonical correspondence analysis (CCA) explain $69.53 \%$ of the variability of the species Axis 1 explains at $29.80 \%$ and axis 2 at $17.72 \%$ the correlation between environmental parameters and earthworms. The parameters related to the axis 1 are the $\mathrm{pH}$, the litter and the water content and the axis 2 by the gradient of the organic matter. The earthworms forming axis 1 are: Dichogaster baeri, Dichogaster terrae nigrae, Dichogaster agilis, Dichogaster leyori, Chuniodrilus zielae, Millsonia ghanensis, Sthulmania porifera, Hyperiodrilus africanus and Millsonia omodeoi. Agastrodrilus multivesiculatus and Chuniodrilus palustris form axis 2 (Figure 3).

\section{Forest}

The proportion explained by the relationship between earthworms and environmental parameters was $75 \%$ (Table 6a). The canonical coefficients of the parameters are presented in Table $6 \mathrm{~b}$ and the scores of each earthworm species in Table $6 c$. 
The first four axes of the canonical correspondence analysis (CCA) account for $83.76 \%$ of the variability of the species. Axis 1 explains to $59 \%$ and axis 2 to $16 \%$ the correlation between environmental parameters and earthworms. The parameter represented by axis 1 is the water content and alone accounts for about $60 \%$ of the distribution of earthworms in the soil. Axis 1 was represented by the species Agastrodrilus multivesiculatus, Dichogaster agilis, Dichogaster baeri, Dichogaster terrae-nigrae, Dichogaster notabilis, Sthulmania porifera and Millsonia omodeoi. Litter biomass, organic matter content and $\mathrm{pH}$ represent axis 2. These parameters account for about $16 \%$ of the distribution of earthworms in forests. The earthworms linked to the axis 2 are: Chuniodrilus zielae, Dichogaster saliens and Hyperiodrilus africanus (Figure 4).

Apparently, the environmental variables measured (Biomass of litter, organic matter, soil moisture and $\mathrm{pH}$ are not sufficient to predict the main variation in earthworm species dispersion, but they do predict a substantial part of the remaining variation.

Table 1: Number of species observed, Sample coverage (ratio of the observed species richness as per cent of the estimated species richness), Shannon-Weaver index and Evenness in each habitat.

\begin{tabular}{lcccc}
\hline Habitats & Number of species & Sample coverage & Shannon-Weaver index & Evenness \\
\hline Grassy savanna & 12 & 84 & 1,89 & 0,98 \\
Woody savanna & 13 & 95 & 2,12 & 0,98 \\
Forest & 12 & 88 & 2,19 & 0,98 \\
\hline
\end{tabular}

Table 2: Density of earthworms (ind. $\mathrm{m}^{-2}$ ) in the three habitats (forest, woody and grassy savannas).

\begin{tabular}{lccc}
\hline Earthworm species & Grassy savanna & Woody savanna & Forest \\
\hline Agastrodrilus multivesiculatus & $1.38 \pm 2.50$ & $1,38 \pm 2,97$ & $0,96 \pm 2,26$ \\
Chuniodrilus palustris & $32.37 \pm 31.14$ & $11,46 \pm 16,82$ & $33,92 \pm 41,63$ \\
Chuniodrilus zielae & $3.57 \pm 6.25$ & $0,90 \pm 2,51$ & $3,14 \pm 7,47$ \\
Dichogaster agilis & $6.24 \pm 5.58$ & $20,80 \pm 20,11$ & $53,49 \pm 40,67$ \\
Dichogaster baeri & $0.32 \pm 1.70$ & $5,65 \pm 22,64$ & $6,4 \pm 9,04$ \\
Dichogaster leyori & 0 & $0,05 \pm 0,46$ & 0 \\
Dichogaster saliens & $0.37 \pm 1.63$ & $0,48 \pm 1,73$ & $2,77 \pm 6,06$ \\
Dichogaster terrae nigrae & $0.05 \pm 0.46$ & $1,28 \pm 2,64$ & $0,26 \pm 1,00$ \\
Hyperiodrilus africanus & $0.32 \pm 1.09$ & $1,12 \pm 4,38$ & $14,61 \pm 33,84$ \\
Millsonia ghanensis & $0.05 \pm 0.46$ & $1,22 \pm 2,70$ & $1,12 \pm 3,19$ \\
Millsonia lamtoiana & $0.21 \pm 0.90$ & $0,8 \pm 1,85$ & $0,05 \pm 0,46$ \\
Millsonia omodeoi & $20.21 \pm 11.63$ & $26,18 \pm 21,13$ & $8,42 \pm 14,43$ \\
Sthulmania porifera & $69.49 \pm 38.03$ & $31,30 \pm 24,26$ & $46,77 \pm 53,22$ \\
Coccons & $8.05 \pm 10.49$ & $2,93 \pm 5,74$ & $4,42 \pm 10,51$ \\
Total & $134,61 \pm 101,42$ & $102,61 \pm 123,81$ & $172 \pm 213,77$ \\
Species number & 12 & 13 & 12 \\
\hline
\end{tabular}


Table 3 : Environmental variables: mass of litter $\left(\right.$ g. $\left./ \mathrm{m}^{2}\right)$, Organic matter $(\%)$, soil moisture content (\%), $\mathrm{pH}$ in three vegetation type.

\begin{tabular}{lccc}
\hline Soil environmental variables & Grassy savanna & Woody savanna & Forest \\
\hline Litter biomass & $31,31 \pm 33,93$ & $219,13 \pm 112,97$ & $373,25 \pm 166,05$ \\
Organic matter & $2,61 \pm 2,18$ & $3,37 \pm 1,4$ & $5,04 \pm 3,64$ \\
Soil moisture content & $5,64 \pm 1,89$ & $6,57 \pm 1,19$ & $7,13 \pm 4,83$ \\
pH & $5,05 \pm 0,29$ & $5,64 \pm 0,42$ & $5,41 \pm 0,39$ \\
& & & \\
\hline
\end{tabular}

Table 4a: Canonical correspondence analysis (CCA) results for grassy savanna.

\begin{tabular}{lccccc}
\hline & & Axis1 & Axis2 & Axis3 & Axis4 \\
\hline Eigenvalues & & 0,176 & 0,104 & 0,087 & 0,068 \\
$\begin{array}{l}\text { Percentage variance } \\
\text { earthworms data and } \quad \text { of } \\
\text { environment variables }\end{array}$ & 27,383 & 16,206 & 13,502 & 10,566 \\
$\begin{array}{l}\text { Cumulative percentage variance } \\
\text { of earthworms data and soil } \\
\text { environment variables }\end{array}$ & 27,38 & 43,59 & 57,09 & 67,66 \\
\begin{tabular}{l} 
Total inertia \\
\hline
\end{tabular} & & & & \\
\hline
\end{tabular}

Table 4b: Canonical coefficients of environment variables for grassy savanna.

\begin{tabular}{lcc}
\hline & Axe 1 & Axe 2 \\
\cline { 2 - 3 } Litter biomass $\left(\mathrm{gm}^{-2}\right)$ & -0.207 & $-0,085$ \\
Organic matter (\%) & -0.059 & $-0,049$ \\
Soil moisture (\%) & -0.059 & -0.049 \\
$\mathrm{pH}$ & 0.39 & 0.041 \\
\hline
\end{tabular}


Table 4c: Scores of each earthworm species for grassy savanna.

\begin{tabular}{lll}
\hline Earthworm species & Axe1 & Axe2 \\
\hline Agastrodrilus multivesiculatus & -0.041 & -0.024 \\
Chuniodrilus palustris & -0.182 & 0.205 \\
Chuniodrilus zielae & 1.600 & -0.186 \\
Dichogaster agilis & -0.262 & -0.029 \\
Dichogaster baeri & 2.583 & -0.086 \\
Dichogaster saliens & -0.312 & -0.140 \\
Dichogaster terrae nigrae & -0.125 & 0.211 \\
Hyperiodrilus africanus & -0.628 & -6.299 \\
Millsonia ghanensis & 2.808 & -0.103 \\
Millsonia lamtoiana & -0.221 & 0.160 \\
Millsonia omodeoi & -0.112 & -0.091 \\
Sthulmania porifera & -0.172 & 0.163 \\
\hline
\end{tabular}

Table 5a: Canonical correspondence analysis (CCA) results for woody savanna.

\begin{tabular}{lcccc}
\hline & Axis1 & Axis2 & Axis3 & Axis4 \\
\hline Eigenvalues & 0.451 & 0.268 & 0.183 & 0.149 \\
$\begin{array}{l}\text { Percentage variance of earthworms data } \\
\text { and environment variables }\end{array}$ & 29.799 & 17.719 & 12.123 & 9.885 \\
$\begin{array}{l}\text { Cumulative percentage variance of } \\
\text { earthworms data and environment variables }\end{array}$ & 29.80 & 47.52 & 59.64 & 69.53 \\
\begin{tabular}{l} 
Total inertia \\
\hline
\end{tabular} & & & & \\
\end{tabular}


Table 5b: Canonical coefficients of environment variables for woody savanna.

\begin{tabular}{lcc}
\hline & Axis 1 & Axis 2 \\
\cline { 2 - 3 } Biomass of litter $\left(\mathrm{g} . / \mathrm{m}^{2}\right)$ & 0.529 & -0.838 \\
Organic matter (\%) & 0.463 & -0.832 \\
Soil moisture (\%) & 0.496 & -0.793 \\
$\mathrm{pH}$ & -0.760 & -0.467 \\
\hline
\end{tabular}

Table 5c: Scores of each earthworm species for woody savanna.

\begin{tabular}{lll}
\hline Earthworm species & Axis1 & Axis2 \\
\hline Agastrodrilus multivesiculatus & -0.217 & 0.862 \\
Chuniodrilus palustris & 0.206 & -0.457 \\
Chuniodrilus zielae & -0.568 & 0.405 \\
Dichogaster agilis & 0.244 & -0.022 \\
Dichogaster baeri & -1.218 & -0.208 \\
Dichogaster leyori & 0.064 & 0.367 \\
Dichogaster saliens & 0.399 & 0.586 \\
Dichogaster terrae nigrae & -0.700 & 0.034 \\
Hyperiodrilus africanus & 0.048 & 0.221 \\
Millsonia ghanensis & -1.375 & -0.388 \\
Millsonia lamtoiana & 0.228 & 0.638 \\
Millsonia omodeoi & -0.060 & 0.156 \\
Sthulmania porifera & 0.085 & 0.023 \\
\hline
\end{tabular}




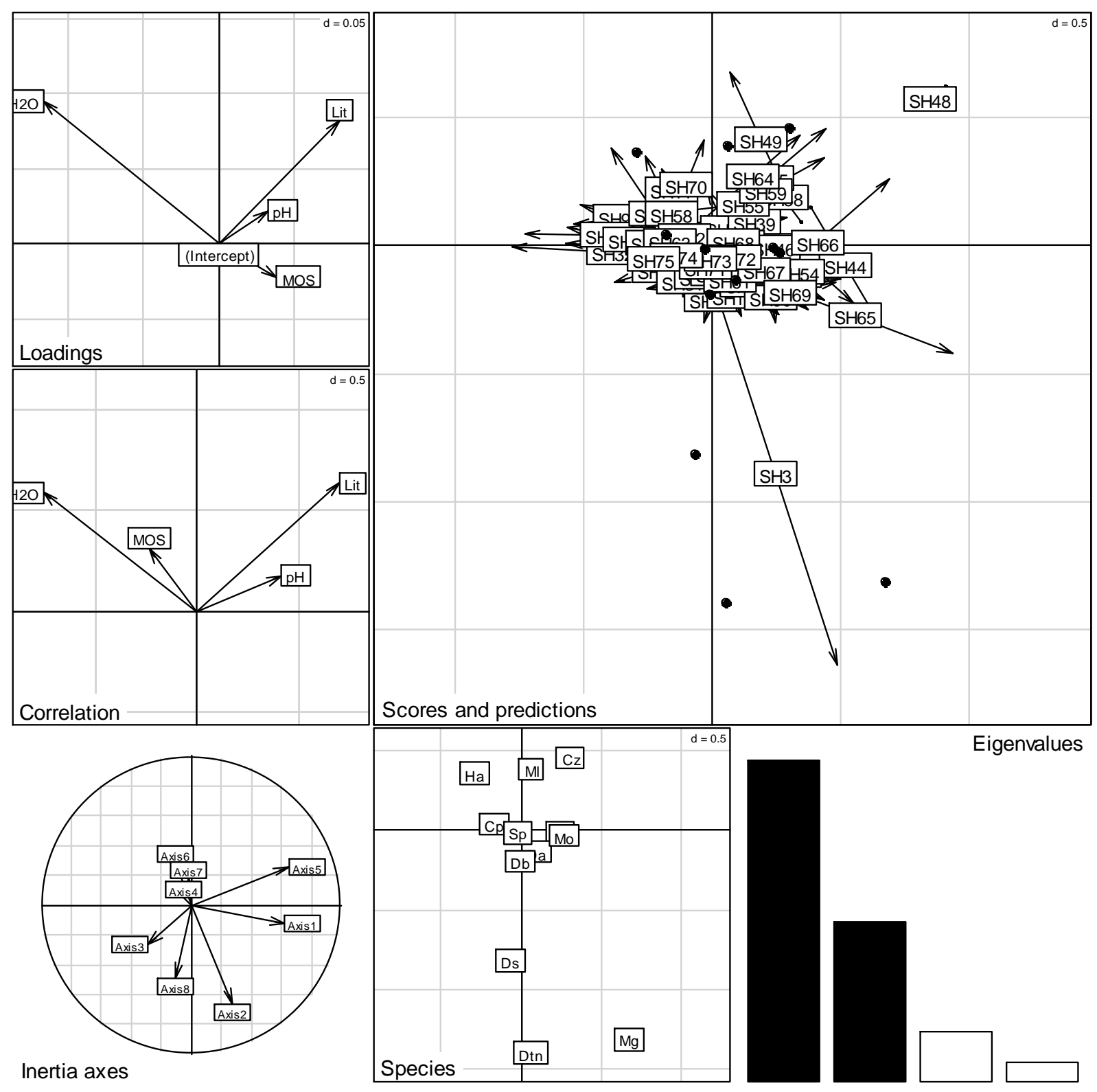

Figure 2: Structure of earthworms' community in grassy savanna.

am : Agastrodrillus multivesiculatus ; cp : Chuniodrilus palustris; $\mathbf{c z}:$ Chuniodrilus zielae $; \mathbf{d a}:$ Dichogaster agilis $\mathbf{d b}$ : Dichogaster baeri; ds : Dichogaster saliens ; dtn : Dichogaster terrae-nigrae ; ha : Hyperiodrilus africanus ; mg : Millsonia ghanensis ; ml : Millsonia lamtoiana ; mo : Millsonia omodeoi ;sp : Stuhlmannia prorifera ; MOS : Sol organic matter; H2O: soil moisture; Lit: Litter; pH ; SH : Grassy savanna. 


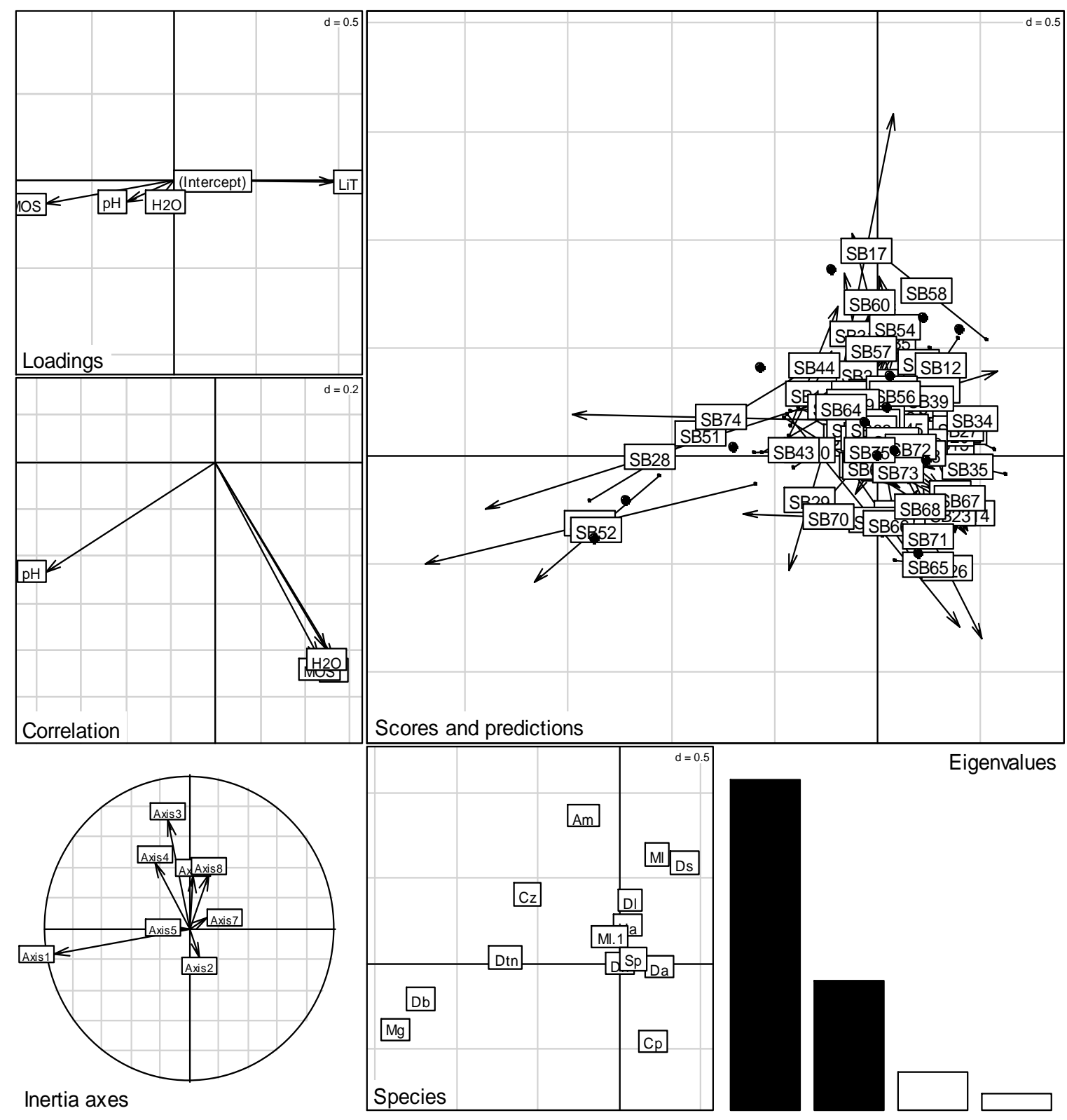

Figure 3: Structure of earthworms' community in woody savanna.

am : Agastrodrillus multivesiculatus; $\mathbf{c p ~ : ~ C h u n i o d r i l u s ~ p a l u s t r i s ~} ; \mathbf{c z}:$ Chuniodrilus zielae $; \mathbf{d a}:$ Dichogaster agilis $\mathbf{d b}$ : Dichogaster baeri; ds : Dichogaster saliens ; dtn : Dichogaster terrae-nigrae; ha : Hyperiodrilus africanus ;mg : Millsonia ghanensis ; ml : Millsonia lamtoiana ; mo : Millsonia omodeoi ;sp : Stuhlmannia prorifera ; MOS : Sol organic matter; H2O: soil moisture; Lit: Litter; $\mathrm{pH}$; $\mathbf{S B}$ : Woody savanna. 


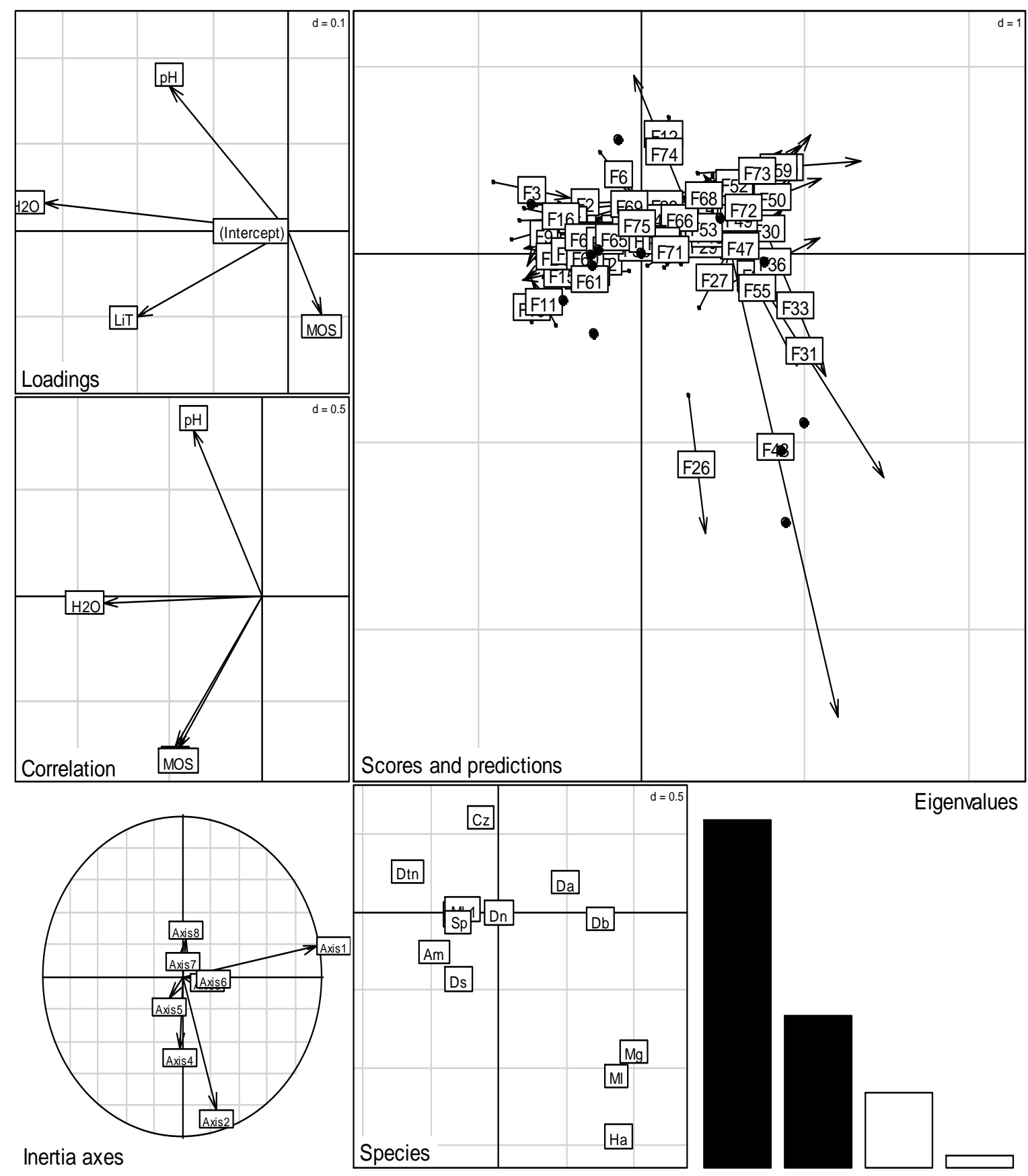

Figure 4: Structure of earthworms' community in forest.

am : Agastrodrillus multivesiculatus; $\mathbf{c p}$ : Chuniodrilus palustris ; $\mathbf{c z}:$ Chuniodrilus zielae $; \mathbf{d a}:$ Dichogaster agilis $\mathbf{d b}$ : Dichogaster baeri ; ds : Dichogaster saliens ; dtn : Dichogaster terrae-nigrae; ha : Hyperiodrilus africanus ; $\mathbf{m g}:$ Millsonia ghanensis ; ml : Millsonia lamtoiana ; mo : Millsonia omodeoi $; \mathbf{s p ~ : ~ S t u h l m a n n i a ~ p r o r i f e r a ~ ; ~ M O S ~ : ~ S o l ~ o r g a n i c ~ m a t t e r ; ~}$ H2O: soil moisture; Lit: Litter; $\mathrm{pH} ; \mathbf{F}$ : Forest. 


\section{DISCUSSION}

\section{Vegetation type and litter biomass}

All vegetation types have the same equitability value and the same ShannonWiever diversity index value. This finding could be explained by a probable stochastic process that create a sampling biases including the sampling period. In the rainy season, rainfall conditions favor survival, fertility and the growth of earthworms (Lee, 1985; Pelosi, 2008). Sampling takes place in the rainy season at this time of year all the earthworms have good reproduction (Vigot and Cluzeau, 2014). In the rainy season the earthworms rise to the surface and therefore accessible to capture. This considerably reduces the sampling effort whatever the type of habitat. According to Rocklin (2003), Shannon-Weaver's diversity indices are very sensitive to sampling effort. The woody savanna contains more species of earthworms followed by grassy savanna and forest with the same number of species. The floristic surveys have shown that the grassy savanna consists mainly of grasses, the woody savanna with grasses and trees both, the forest of trees mainly. Ramanujam et al. (2000) noted that vegetation type influences the diversity and distribution of earthworms. The fact that grasses and trees coexists in woody savanna provides a variability of food resources. This heterogeneity of vegetation is a source of variability of microhabitats beneficial to the appearance of species. This result is corroborated by the work of Decaens et al. (1994), who reported that the more habitat there is the greater the number of species. Mathieu et al. (2010) reported that earthworms prefer habitats to optimum environmental conditions. These conditions affect the welfare of earthworms (Lowe and Butt, 2005).

The biomass of litter is high in forest $\left(373,25 \pm 166,05 \mathrm{~g} . / \mathrm{m}^{2}\right)$. It is moderately high in woody savanna $\left(219,13 \pm 112,97 \mathrm{~g} . / \mathrm{m}^{2}\right)$ and very low in grassy savanna $(31,31 \pm 33,93$ g. $\left./ \mathrm{m}^{2}\right)$.

The difference between litter biomasses in different habitats could be explained by the unequal density and diversity of plants in these habitats. The vegetation cover of each habitat is mainly at the origin of the litter of this habitat. The low litter biomass observed in grassy savanna may be due to the topographic position of grassy savanna. The grassy savanna is located at the top of the slope during the rains the soils are leached thus causing the loss of a quantity of litter. Grassy savanna is burned annually in midJanuary. As it passes, the fire consumes everything making the soil empty and thus contributes to the reduction of the litter. In grassy savanna, we also noticed during our sampling that the vegetation is covered with clumps of grasses but the soil is empty.

In woody savanna, the vegetation is mixed (it is composed of grasses and trees). The amount of litter biomass is certainly due to this mixture (Hagedorn et al., 2008). These savannas also undergo the action of fire, which can reduce the amount of litter.

In the forest, the amount of litter is high. This could be explained by the fact that in the forest there are more large trees that produce large amounts of bedding on the soil surface. Also the vegetal cover contributes to reduce the effects of erosion thus allowing maintenance of the litter on the surface of the ground.

\section{Earthworms' density in relation to organic matter and soil moisture content, and $\mathbf{p H}$}

Whatever type of habitat is sampled, the canonical correspondence analysis show that soil moisture influences the earthworm community. Bouché (1972) showed that water represents about $86 \%$ of the weight of earthworms. This shows the vital importance of water in their dynamics. Also our sampling took place in the rainy season. At this season, rainfall conditions favor survival, fertility and the growth of earthworms (Lee, 1985; Pelosi, 2008), thus enabling good reproduction of earthworms (Vigot and Cluzeau, 2014). The high density of earthworms observed is due to the fact that in forest, canopy cover of tree helps to keep forest soils more humid.

The canonical correspondence analysis show that, in grassy savanna organic matter also influences earthworms. The low density 
of earthworms in grassy savanna is therefore due to the low organic matter content in the soils of grassy savannas because lower organic matter soils do not support high densities of earthworms (Edwards and Bohlen, 1996). So the density of earthworms increases with the organic matter content (Valchovski, 2016).

In woody savanna, earthworms community is explain by the $\mathrm{pH}$, the biomass of litter in addition to water. Our results show that the density of earthworms is slow in woody savanna. The $\mathrm{pH}$ mean of woody savanna is $5,64 \pm 0,42$. This value is within the $\mathrm{pH}$ range proposed by Satchell (1967) which is 5.0 to 7.4. The low density of earthworms is related to the quality of litter founded in woody savanna. This corroborates the findings of Manna et al. (2003) who determined that the different forest litter materials used during decomposition affected the survival and reproduction rates of the species of earthworm.

In general, the canonical correspondence analysis shows that soil environment variables account for $67.66 \%$ of the variance of earthworms in grassy savanna, $69.53 \%$ in woody savannah and $83.76 \%$ in forest. The unexplained variance may be due to the phenomenon of competition (Ettema and Wardle, 2002), that is to a complementarity between the niches (Ehouman, 2012), interspecific relationships (Ehouman, 2012), the presence of predators (Edwards and Lofty, 1977; Lee, 1985), the type of vegetation (Ramanujam et al., 2000) their reproductive potential and competition (Ettema and Wardle, 2002) or the gregarious behavior of earthworms (Rossi and Lavelle, 1998) or fire because in Lamto the savannas are burned annually in mid-January. Fire can act directly on earthworms epigeic species or indirectly on endogenous species and thus contributes to modifying the composition of the structure of earthworms found in grassy and woody savannas. According to Lavelle (1978), some reach their maximum of reproduction in October (end of the rainy season) and its minimum between December and January. The firing takes place in mid-
January when these species are still vulnerable and therefore very sensitive to fire. Mutualism with other soil organisms can also explain the distribution of earthworms in the soil (Trigo et al., 1999).

\section{Conclusion}

This study has provided new information regarding the effects of abiotic factors of soil on diversity and distribution of earthworms species. In this study, the structure of the earthworms' communities varies according to the type of vegetation and the soil parameters. The woody savanna contained the greatest number of earthworm species followed by the grassy savanna and the forest that had the same number of species. Litter biomass, soil moisture and organic matter contents are higher in forest followed by woody and grassy savannas. The forest has the highest density of earthworms. It is followed by grassy and woody savannas. The moisture of soil influence the distribution of earthworm in forest. In grassy savanna the distribution of earthworm depends on soil moisture and organic matter. In woody savanna, the distribution of earthworm depends on soil moisture, $\mathrm{pH}$ and biomass of litter.

\section{COMPETING INTERESTS}

The authors declare that they have no competing interests.

\section{AUTHORS' CONTRIBUTIONS}

This work was carried out in collaboration between all authors. NMS collected the data. NME analyzed the data. NMS and NME wrote the first draft of the manuscript. TM and TS contributed in reading and correcting the manuscript for the final version before submission. All authors read and approved the final manuscript.

\section{ACKNOWLEDGMENTS}

The authors wish to express their thanks to Professor Kolo YEO, Director of the Ecology Research Station of Lamto for the material and logistical support in the realization of this study. We also thank 
Professor Souleymane Konaté, Director of Ecology and Biodiversity Research Unit of Nangui Abrogoua University, for the moral and material support he has given us.

\section{REFERENCES}

Baize D. 2000. Guide des Analyses en Pédologie: Techniques et Pratiques. Editions INRA : Paris ; $260 \mathrm{p}$.

Bouché MB. 1972. Lombrics de France, Ecologie et systématique, Institut national de la recherche Agronomique, Annales de Zoologie-Animal Ecology. No hors série, Paris, 671P. Paris.

Csuzdi C, Tondoh JE. 2007. New and littleknown earthworm species from the Ivory Coast (Oligochaeta: Acanthodrilidae: Benhamiinae and Eudrilidae). Journal of Natural History, 41: 2551-2567. DOI: https://doi.org/10.1080/00222930701742 629.

Decaëns $T$, Lavelle $P$, Jiménez Jaen JJ, Escobar G, Rippstein G. 1994. Impact of land management on soil macrofauna in the Oriental Llanos of Colombia. Eu. J. Soil Bid., 30(4): 157-168.

Decaens T, Jiminez J. 2002. Earthworm communities under an agricultural intensification gradient in Colombia. Plant and Soil, 240: 133-143. DOI: http/dx.doi.org/10.1023/A:10158446106 04

Edwards CA, Lofty JR. 1977. Biology of Earthworms (2nd edn). Chapman and Hall: London; 495p.

Edwards CA, Bohlen PJ. 1996. Biology and Ecology of Earhworms ( $\left.3^{\text {rd }} \mathrm{edn}\right)$. Chapman and Hall: London; 300p.

Ehouman NM, Tiho S, Dagnogo M. 2012. Cooccurrence of earthworms in Lamto savanna: A null model analysis of community structure. European Journal of Soil Biology, 53 : 40-47. DOI: http://dx.doi.org/10.1016/j.ejsobi.2012.0 8.007 .

Empwal FM, Lemtiri A, Manzanza CK, Sudi CK, Komanda JA, Yeto EBW, Francis F. 2017. Abondance et diversité des communautés lombriciennes dans la
Réserve et Domaine de Chasse de Bombo-Lumene (Kinshasa). Int. J. Biol. Chem. Sci., 11(1): 387-396. http://ajol.info/index.php/ijbcs

Ettma CH, Wardle DA. 2002. Spatial soil ecology. Trends Ecology Evolution, 17(4): $\quad 177-183 . \quad$ DOI: http://dx.doi.org/10.1016/S0169-5347 (02)02496-5

Fokam Z, Nana PA, Bricheux G, Vigues B, Bouchard P, Ngassam P, Sime-ngando T. 2016. Correlation between some environmental variables and abundance of Almophrya mediovacuolata (Ciliophora: Anoplophryidae) endocommensal ciliate of an anecic earthworms (Oligochaeta: Annelida) in Bambui (North-West Cameroon). Int. J. Biol. Chem. Sci., 10(5): 1983-1997. http://ajol.info/index.php/ijbcs

Gastine A, Scherer-Lorenzen M, Leadley P. 2003. No consistent effects of plant diversity on root biomass, soil biota and soil abiotic conditions in temprerate grassland communties. Applied Soil Ecology, 24(3): 101-111. DOI: http//hdl.handle.net/11858/00-001M0000000E-D04-3

Gonzalez G, Garcia E, Cruz V, Boges S, Zalamea M and Rivera M M. 2007. Earthworm communities along an elevation gradient in North eastern Puerto Rico. Europ. J. Soil Biol., 43: 2432. DOI: 10.1016/j.ejsobi.2007.08.044

Hagedorn F, Van Hees PAW, Handa IT, Hätte nschwiler S. 2008. Elevated atmospheric $\mathrm{CO}_{2}$ fuels leaching of old dissolved orga nic matter at the alpine treeline. Global B iogeochemical Cycles, 22. DOI: 10.1029/2007GB003026.

Jongman RHG, Ter Braak C, Van Tongeren OFR. 1995. Data analysis in community and landscape ecology. Cambridge university press. Biometrics, 46(1). DOI: 10.2307/2531665.

Koné AW, Edoukou EF, Gonnety JT, N'dri ANA, Assemien LFE, Angui PKT, Tondoh J. 2012. Can the shrub Chromolaena odorata (Asteraceae) be considered as improving soil biology and 
plant nutrient availability? Agroforest

Syst, 85: 233-245. DOI: 10.1007/s10457-012-9497-5

Lalthanzara H, Ramanujam SN, Jha LK. 2011. Population dynamics of earthworms in relation to soil physicochemical parameters in groforestry systems of Mizoram, India. J Environ Biol, 32(5): 599-605. DOI : www.jeb.co.in.

Lavelle P. 1978. Les vers de terre de la savane de Lamto (Côte d'ivoire) : peuplements, populations et fonctions dans l'écosysteme. Doctorat thesis, University paris VI. 301 p.

Lebreton JD, Chessel D, Richardot-Coolet M, Yoccoz N. 1988. L'analyse des relations espèces - milieu par l'analyse canonique des correspondances. I. variable de milieux quantitatifs. Acta Oecologia Oecology Generalis, 9(2): 137-151.

Lee KE. 1985. Earthworms, Their Ecology and Relationships with Soils and Land Use. Academic Press: New York; 411p.

Lowe CN, Butt KR. 2005. Culture techniques for soil dwelling earthworms: a review. Pedobiologia, 49(5): 401-413. DOI: https://doi.org/10.1016/j.pedobi.2005.04. 005.

Manna MC, Jha S, Ghosh PK, Acharya CL. 2003. Comparative efficacy of three epigeic earthworms under different deciduous forest litters decomposition. Bioresource Technology, 88(3): 197206.

Mathieu J, Barot, Blouin M, Caro G, Decaëns T, Dubs F, Dupont L, Jouquet P, Nai P. 2010. Habitat quality, conspecific density, and habitat pre-use affect the dispersal behaviour of two earthworm species, Aporrectodea icterica and Dendrobaena veneta, in a mesocosm experiment. Soil Biology \& Biochemistry, 42: 203-209. DOI: 10.1016/j.soilbio.2009.10.018.

Milau F, Kachaka S, Aloni K, Mvumbi M, Francis F. 2015. Incidence de la déforestation sur les catégories écologiques des vers de terre dans le domaine et Reserve de Chasse de Bombo
Lumene (Kinshasa). Tropicultura, 33(3): 209-217.

DOI: http://hdl.handle.net/2268/186532

Pelosi C. 2008. Modelisation de la dynamique d'une population de vers de terre Lumbricus terrestris au champ. Institut des sciences et industries du vivant et de l'environnement, thèse de doctorat, Paris, France, 95pp.

Moreno MT, Audesse P, Giroux M, Frenette N, Cescas M. 2001. Comparaison entre la détermination de la matière organique des sols par la méthode de Walkleyblack et la méthode de perte au feu. Agrosol , 12(1): 49-58.

Rajkhowa DJ, Bhattacharyya PN, Sarma AK and Mahanta K. 2014: Diversity and distribution of Earthworms in different soil habitats of Assam, North-East India, an Indo-Burma Biodiversity Hotspots. Proc. Natl. Acad. Sci., India, Sect. B Biol. Sci. DOI: 10.1007/s40011-0140380-1

Ramanujam SN, Roy B, Jha LK. 2000. Inventory studies on the earthworm population in agroforestry systems of Mizoram. Proc. Intl. Workshop on agroforestry and forest products, Aizawl. pp. 191-194.

Rocklin D. 2003. Etude comparative de différents indices de diversité (indice de Shannon, indices taxonomiques) sur les peuplements de poissons lagunaires. Mémoire d'Initiation à la Recherche. Maîtrise de Biologie des Populations et des Ecosystèmes. Université de Montpellier II Sciences et Techniques.

Rossi JP, Lavelle P. 1998. Earthworm aggregation in the savanna of Lamto (Côte d'Ivoire). Applied Soil Ecology,7: 195-199.13.

Satchell JE. 1967. Lumbricidae. In Soil Biology, Burges A, Raw F (eds). Academic Press: London; 259-322. 93.

Savadogo OM, Ouattara K, Ouedraogo I, Kaboré SS, Traoré M, Barron J, Gordon L, Paré S, Zombré NP. 2016. Vegetation improvement and soil biological quality in the Sahel of Burkina Faso. Int. J. Biol. 
Chem. Sci., 10(3): 1048-1058. http://ajol.info/index.php/ijbcs.

Scullion J, Malik A. 2000. Earthworm activity affecting organic matter, aggregation and microbial activity in soils restored after open cast mining for coal: Soil Biology and Biochemistry, 32: 119-126. DOI: https://doi.org/10.1016/S00380717(99)00142-X

Singh S, Singh J, Pal Vig A. 2016. Effect of abiotic factors on the distribution of earthworms in different land use patterns. The Journal of Basic \& Applied Zoology, 74: 41-50 DOI: https://doi.org/10.1016/j.jobaz.2016.06.0 01

Traoré M, Lompo F, Ayuke F, Ouattara B, Ouattara K, Sedogo M. 2012. Influence des pratiques agricoles sur la macrofaune du sol : cas de l'enfouissement de la paille et du fumier. Int. J. Biol. Chem. Sci., 6(4): 1761-1773. DOI: http://dx.doi.org/10.4314/ijbcs.v6i4.31
Trigo D, Barois I, Garvin MH, Huerta E, Irisson S, Lavelle P. 1999. Mutualism between earthworms and soil microflora. Pedobiologia, 43(6): 866-873. DOI: http://www.documentation.ird.fr/hor/fdi: 010021122

Tripathi G, Bhardwaj P. 2004. Earthworm diversity and habitat preferences in arid regions of Rajasthan. Zoo's Print J., 19 (7): $\quad 1515-1519 . \quad$ DOI : http://dx.doi.org/10.11609/JoTT.ZPJ.107 4.1515-9

Valchovski H. 2016. Influence of Soil Organic Matter Content on Abundance and Biomass of Earthworm (Oligochaeta: Lumbricidae) Populations. ECOLOGIA BALKANICA, 8(1): 107110. DOI: http://web.uniplovdiv.bg/mollov/EB/2016_vol8_iss1/1 07-110_eb.16116.

Vigot M, Cluzeau D. 2014. Les vers de terre. Chambre d'Agriculture de la Vienne, Vienne ; 10p. 